\title{
（2）超高速応答 極細・極薄熱電対
}

株式会社アンベエスエムティ*1

\section{1. はじめに}

従来, 温度測定には価格が比較的安くかつ容易に使用できる 熱電対が広く使用されている. 熱電対は広い温度範囲を計測で き，かつデータをパソコンへ容易に取り込めることも好都合で ある。

17 年前，当時 $0.3 \mathrm{~mm}$ ピッチ $\mathrm{QFP}$ 電子部品が基板に搭載さ れようとしていた。リード幅は約 $0.15 \mathrm{~mm}$ であり，このリード の温度測定に従来の先端が $\phi 0.5 \mathrm{~mm}$ 程度の熱電対をはんだ接合 して温度測定することに疑問を感じたのが発端となった．真の 温度を測定するにはどうしたらよいだろうか？

正確な温度測定は実験などに打ける重要な基本的データであ るにもかかわらず，大きな課題点があるのではないかとの疑念 が浮かんだ。

\section{2. 超高速応答 極細・極薄熱電対の開発}

超高速応答熱電対の条件としては基本的に先端感温部の昇温 速度が大きく，先端感温部からの放熱が小さいことが必要であ る. 即ち,

(1) 先端感温部の熱容量を小さく抑える.

(2) 先端感温部の伝熱面積を大きくする.

(3) 先端に続く熱電対線を細くする.

（希薄な空気に比較し熱電対は金属であり熱伝導性が高く 熱電対線自体を通過して熱が逃げやすいため)

(4) 応答性に深くかかわる先端部 (数ミリオーダー) 以外は, 取扱い上最低でも $100 \mu \mathrm{m}$ 径は必要となる。

上記(1)(3)(4)を満たすのが極細熱電対で，最も高速応答. 更に(1)(2)を満たすのが極薄熱電対であり，物体表面の 温度測定への適応性を重視しており，ある程度の頑丈さ を併せ持つ。

\section{3. 超高速応答熱電対の仕様と用途例}

弊社の極細熱電対（主として K 型熱電対）は，先端部のみ $13 \mu \mathrm{m}, 25 \mu \mathrm{m}, 50 \mu \mathrm{m}$ クロメルアルメル線を接合したものである. また，極薄熱電対は先端部の厚さを，例えば $10 \sim 80 \mu \mathrm{m}$ 程度と 薄くすることで主として物体表面温度測定用として開発したも のである。この極細・極薄熱電対は，従来にない超高速応答で 固体・液体・気体を問わず温度計測を可能とする。例えば，数 $1000 \mathrm{rpm}$ で回転する自動車エンジンシリンダー内のガス温度, 車衝突時瞬間的に膨らむエアーバッグ用インフレーターガス温 度，パッチクランプと呼ばれる 1 個の生体細胞の例えば $20 \mathrm{msec}$ の短時間に打ける瞬間的温度変化, IC チップのジャッ クション温度，フリップチップ IC のアンダーフィルの温度, 火薬類の爆発時温度変化, 短時間で温度変化するバイトやエン ドミル先端の温度，呼吸時の排気温度など先端技術の中枢（宇 宙, 航空, 原子力, 半導体, ソーラ一, 医学, 農業その他の設 備）で幅広く使用されている。

\section{4. 製作熱電対例と測定温度データ}

图 1 はエンジン用 2 線式 $\mathrm{K}$ 型熱電対 $(25$ および $50 \mu \mathrm{m})$ で同じ 空間温度を測定し, 各温度データから真の温度を計算で求める.

先端が $\phi 0.5 \mathrm{~mm}$ 程度のボール状熱電対では高速で回転する工 ンジン内部の温度は測定不可能（ほとんど温度変化は見られな い）であったが, 当社極細熱電対によって初めて可能となった. 現在，顧客からのデータは公表できないので，図 2 に高速応答 の一例として超小型スターリングエンジン（ガタ有り）のシリ ンダー内ガス温度の測定例を示す．ただし，燃料は外部からろ うそく状で加熱.

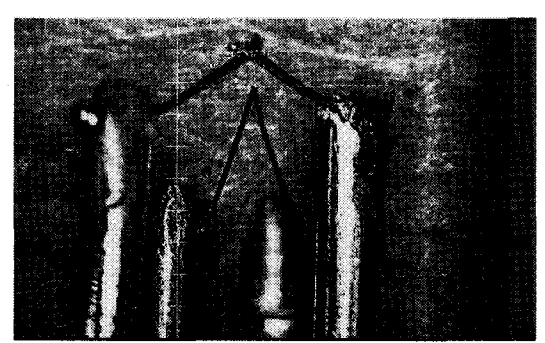

図 1 エンジン用 2 線式 $\mathrm{K}$ 型熱電対（25 および $50 \mu \mathrm{m} ）$

スターリングエンジンのシリンダー内ガス温度

測定サンプリングタイム $: 1 \mathrm{msec}$

熱電対タイプ：極細熱電対 $25 \mu \mathrm{m}$ ( $\phi 2 \mathrm{~mm}$ の SUS 管入り $)$

横軸 1 マス $50 \mathrm{msec}$

回転数 約 $1090 \mathrm{rpm}$ (1 サイクル $55 \mathrm{msec}$ )

温度変化 $185 \sim 220^{\circ} \mathrm{C}$

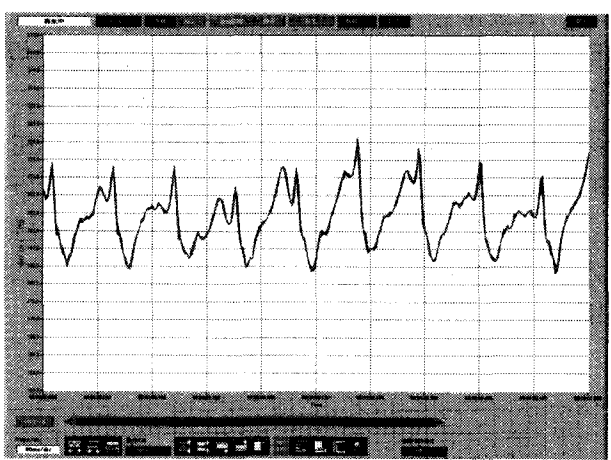

図 2 スターリングエンジン (模型) 筒内ガス温度

最近では火薬の爆発など, さらに高速（ $\mu \mathrm{sec}$ オーダー，上記 の $1 / 1000$ の時間) で変化する温度を $25 \mu \mathrm{m}$ 極細熱電対で十分に 測定することが可能となっているが，詳細はデータがまとまった 時点で発表したい，従来にない短時間領域の温度測定が可能と なり，温度予測ソフトなどと連携すればその効果は計り知れない．

\section{5. 販売実績}

昨年度の販売実績は各種超高速応答熱電対を中心に合計で約 12500 本以上を出荷している.

当社の特街は顧客のニーズ, 即ち, 対象物体 - 取付け部の大 きさ・測定温度幅・要求応答性・測定時間・ノイズの有無など を聞き，原則すべてカスタムメイドで要望に応じている.

現在，わが国では当社製の超高速応答熱電対が広く使用され ているが，海外では残念ながら当社の宣伝が十分でないことも あり, 使用されているのはごく一部に限定されている. 今後, これを機会に一層海外への搪販を図りたい

\section{6. むすび}

これまで多くの顧客の要望を実現し，社内の実験でも，今さ らながら特に極細熱電対は底知れない応答性を持っている(す なわちより真の温度を測定できる) ことを実感している. 応答 性の限界を把握するには爆楽，あるいはコンデンサに蓄えた電 気エネルギーを瞬間的にショート発熱させるなどでしかその限 界は把握できない．時定数を測定することは長年の目標である が, 異なる温度等囲気への移動時間を数 $\mu \mathrm{sec}$ 以下にする必要 があり，通常これは不可能である. 別の方法でその応答性を表 示できないか模索した心. 